FOLIA POMERANAE UNIVERSITATIS TECHNOLOGIAE STETINENSIS

Folia Pomer. Univ. Technol. Stetin., Oeconomica 2018, 347(93)4, 87-102

Błażej SUPROŃ

\title{
ANALIZA SYTUACJI EKONOMICZNEJ MAKYCH I ŚREDNICH PRZEDSIĘBIORSTW SEKTORA TRANSPORTU DROGOWEGO TOWARÓW W WOJEWÓDZTWIE ZACHODNIOPOMORSKIM W KONTEKŚCIE ICH ROZWOJU
}

\author{
ANALYSIS OF THE PROPERTY AND FINANCIAL SITUATION OF SMALL \\ AND MEDIUM ENTERPRISES IN THE ROAD TRANSPORT SECTOR \\ IN THE WEST POMERANIAN VOIVODESHIP IN THE CONTEXT \\ OF THEIR DEVELOPMENT
}

Katedra Ekonomii i Rachunkowości, Zachodniopomorski Uniwersytet Technologiczny w Szczecinie ul. Żołnierska 47, 71-210 Szczecin, ORCID: 0000-0002-7432-1670, e-mail:bsupron@zut.edu.pl

\begin{abstract}
Summary. The aim of the research was to assess the structure of property balance of enterprises in the road transport sector located in the West Pomeranian Voivodeship. In addition, as part of the study, an analysis of the impact of individual financial and property ratios on the development of transport enterprises was made. The study covered a group of 103 enterprises for which it was possible to obtain full financial data for the years 2008-2014-28 micro, 63 small and 12 medium-sized enterprises. In the audited period, the general level of indebtedness of the surveyed enterprises increased and a high share of foreign sources of financing occurred. The overall profitability of sales of transport services of the surveyed enterprises was at a relatively low level. The development of enterprises in the audited period was financed mainly by incurring financial liabilities, which resulted in an increase in the total indebtedness in 2014 by $32.9 \%$ compared to 2008 .
\end{abstract}

Słowa kluczowe: rozwój przedsiębiorstw, małe i średnie przedsiębiorstwa, transport drogowy, analiza ekonomiczna.

Key words: development of enterprises, small and medium enterprises, road transport, economic analysis.

\section{WSTĘP}

Analiza struktury kapitałowo-majątkowej przedsiębiorstw pozwala ocenić, jakie zmiany w nich zachodziły, a także określić ich kierunek. Niezbędnym narzędziem wykorzystywanym do oceny tej struktury jest bilans przedsiębiorstwa. Podstawowym aspektem funkcjonowania przedsiębiorstwa na rynku i jego rozwoju jest optymalizacja procesu zarządzania składnikami bilansu, który dzieli się na majątek trwały i obrotowy (Bórawski 2008).

Badanie struktury bilansu oraz jego zmian umożliwia przeprowadzenie analizy finansowej i majątkowej przedsiębiorstw, pomiar płynności, wielkości sprzedaży oraz ocenę gospodarowania zarówno majątkiem trwałym, jak i obrotowym. Analiza bilansu majątkowego na przestrzeni kilku lat pozwala ocenić kierunki rozwojowe przedsiębiorstw. Z tego powodu za główny problem badawczy w niniejszej publikacji uznano zmiany zachodzące w majątku trwałym i obrotowym oraz źródłach jego finansowania, co stanowi podstawę wielo-wymiarowej oceny badanej grupy przedsiębiorstw. 
Celem badań była ocena struktury bilansu majątkowego przedsiębiorstw sektora transportu drogowego mających swoją siedzibę w województwie zachodniopomorskim. Ponadto przeprowadzono ocenę zmian wartości składników bilansu majątkowego przedsiębiorstw w latach 2008-2014.

\section{WPŁYW SYTUACJI FINANSOWEJ I MAJĄTKOWEJ NA ROZWÓJ PRZEDSIĘBIORSTW}

Jak wskazuje Micuła (2013) rozwój przedsiębiorstwa prowadzi do zmian poziomu i struktury jego elementów składowych. W tych kategoriach wyróżniamy elementy materialne (majątek trwały i obrotowy znajdujący odzwierciedlenie w aktywach przedsiębiorstwa) oraz elementy pozamaterialne.

Rozwój przedsiębiorstwa jest ściśle związany z pojęciem zmiany, której istota polega na przejściu przedsiębiorstwa ze stanu dotychczasowego do innego, jednoznacznie odmiennego. Jak wskazuje Kożuch (2008) uniwersalnym celem istnienia każdego przedsiębiorstwa jest jego istnienie rozumiane jako przetrwanie lub rozwój.

Rozwój przedsiębiorstwa często utożsamiany jest także z jego wzrostem. Należy jednak zaznaczyć, że rozwój oznacza przechodzenie od struktur mniej efektywnych, dysharmonijnych do struktur harmonijnych, umożliwiających większą efektywność gospodarowania, natomiast wzrost jest raczej kategorią ilościową. Rozwój przedsiębiorstwa jest więc środkiem realizacji celu przedsiębiorstwa, którym jest maksymalizacja zysków oraz ekspansja. Wzrost natomiast z jednej strony stanowi jeden z podstawowych środków realizacji celu przedsiębiorstwa, $z$ drugiej strony jest z tym celem skorelowany (Penc 1997).

Pierścionek (1998) wskazuje, że rozwój to proces dostosowania zapewniający przedsiębiorstwu osiągnięcie i utrzymanie przewagi konkurencyjnej, co stanowi niezbędny warunek utrzymania się na rynku. Natomiast wzrost jako kategoria ilościowa oznacza powiększanie zasobów przedsiębiorstwa, z reguły prowadzi do wzrostu udziału w rynku lub utrzymaniu tego udziału, ale i do dywersyfikacji działalności (Pierścionek 1998).

Przyjmuje się jednak, że pojęcia rozwoju i wzrostu są powiązane ze sobą. Rozwój potrzebuje wzrostu przedsiębiorstwa. Następuje on z reguły w wyniku zmian w dotychczasowym systemie wartości przedsiębiorstwa, natomiast rozwój następuje poprzez wiele zmian wewnętrznych, które skutkują zwiększeniem rozmiarów organizacji i znajdują odzwierciedlenie w jej charakterystyce (Czarnecki 2011).

Powszechnie stosowane metody pomiaru efektywności opierają się na podejściach: wskaźnikowym i parametrycznym. Pierwsze podejście polega na konstruowaniu relacji pomiędzy różnymi wielkościami. W tym celu wykorzystuje się wskaźniki rentowności, opłacalności i produktywności. Przy tym ważne są odpowiednie oszacowanie przyjętych miar i właściwa interpretacja obliczonych wskaźników. Podejście parametryczne z kolei opiera się na znanej w teorii mikroekonomii funkcji produkcji. W przypadku metod parametrycznych występuje jednak podstawowy problem związany z przeprowadzeniem pełnego rachunku bazującego na funkcji produkcji. Na przeszkodzie stoi nie tylko złożoność metodyki, ale przede wszystkim bariera braku odpowiednich danych (Szymańska 2010).

Analiza rozwoju przedsiębiorstwa powinna więc opierać się na ogólnej ocenie sytuacji majątkowej i finansowej. Tylko przedsiębiorstwo, które poprawia swój stan ekonomiczny, można uznać za rozwijające się. Ponieważ zjawisko rozwoju przedsiębiorstwa mierzone jest w kategoriach jakościowych, konieczne jest wartościowanie danych ilościowych w sposób umożliwiający dokonanie analizy jakości oraz porównania z innymi jednostkami. 


\section{MATERIA I METODY}

Badanie obejmowało analizę sytuacji majątkowej i finansowej przedsiębiorstw sektora transportu drogowego w województwie zachodniopomorskim w latach 2008-2014. Wybór horyzontu czasowego podyktowany był koniecznością zestawienia zachodzących zmian w czasie oraz wykluczenia przypadkowych tendencji. Dobór badanych przedsiębiorstw miał charakter celowy i został przeprowadzony na podstawie bazy danych przedsiębiorstw posiadających międzynarodową licencję w zakresie transportu ładunków, udostępnioną przez Biuro ds. Transportu Drogowego. Z otrzymanej bazy danych została wybrana lista przedsiębiorstw, które prowadziły $\mathrm{w}$ badanym okresie działalność gospodarczą przez minimum 5 lat oraz posiadały licencję w zakresie międzynarodowego transportu rzeczy.

W wyniku analizy danych otrzymano listę 705 przedsiębiorstw, które stanowiły 36,3\% wszystkich jednostek posiadających licencję w 2014 r. Ostatecznie badanie przeprowadzono na grupie 103 przedsiębiorstw, dla których można było wskazać pełne dane finansowe z badanego okresu. W grupie tej znalazło się 28 mikroprzedsiębiorstw, 63 małych i 12 średnich. Dane pozyskano z bazy InfoVerit oraz Krajowego Rejestru Sądowego w postaci sprawozdań finansowych. Informacje dotyczące złożenia sprawozdania finansowego były pozyskiwane dzięki obwieszczeniom Monitora Sądowego i Gospodarczego.

Do badania zakwalifikowano spółki kapitałowe oraz spółki jawne, które były w badanym okresie zobowiązane do składania sprawozdań finansowych. Z powodu braku porównywalności, wynikającej $\mathrm{z}$ prowadzenia $\mathrm{w}$ większości przypadków ewidencji podatkowych, a także z powodu tajemnicy skarbowej zrezygnowano z pozyskania danych przedsiębiorstw osób fizycznych oraz spółek cywilnych. Szczegółowa charakterystyka badanych przedsiębiorstw została przedstawiona w tab. 1.

Tabela 1. Charakterystyka badanych podmiotów

\begin{tabular}{|l|c|c|c|}
\hline \multicolumn{1}{|c|}{ Forma prawna } & $\begin{array}{c}\text { Przedsiębiorstwa } \\
\text { zakwalifikowane do } \\
\text { badania }\end{array}$ & $\begin{array}{c}\text { Przedsiębiorstwa } \\
\text { objęte badaniem }\end{array}$ & $\begin{array}{c}\text { Udział [\%] } \\
\text { przedsiębiorstw objętych } \\
\text { badaniem we wszystkich } \\
\text { przedsiębiorstwach }\end{array}$ \\
\hline Spółka jawna & 39 & 23 & 59,0 \\
\hline Spółka komandytowa & 3 & 2 & 66,7 \\
\hline Spółka komandytowo-akcyjna & 1 & 1 & 100,0 \\
\hline Sp. z o.o. sp.k. & 2 & 1 & 50,0 \\
\hline Spółka z o.o. & 126 & 76 & 60,3 \\
\hline Razem & 171 & 103 & 60,2 \\
\hline
\end{tabular}

Przeprowadzenie badania, jak również uzyskanie wniosków końcowych wymagało zgromadzenia obszernego materiału badawczego obejmującego sprawozdania finansowe ze 103 badanych przedsiębiorstw z lat 2008-2014, co oznacza łącznie 618 bilansów, rachunków zysków i strat oraz pozostałych informacji wchodzących w ich skład. Przedsiębiorstwa przypisano do poszczególnych klas wielkości na podstawie wytycznych rekomendacji Komisji Europejskiej z maja 2003 r. (2003/361/WE). W celu opracowania danych zastosowano metody statystyki opisowej, co związane było z brakiem losowego charakteru próby; wyniki odnoszą się do badanych podmiotów. W opracowaniu wyników wykorzystano metody statystyczne, a także elementy analizy ekonomicznej i finansowej. 


\section{WYNIKI I DYSKUSJA}

W ciągu 6 badanych lat zachodziły dynamiczne zmiany zarówno w obszarze finansowym, jak i majątkowym badanych podmiotów. Były one spowodowane zarówno przekształceniami wewnątrz badanych podmiotów, jak również w ich otoczeniu makroekonomicznym. Ocena tych zmian umożliwia określenie, jak zmieniały się majątek oraz sytuacja finansowa badanych przedsiębiorstw w latach 2008-2014 oraz w jakim stopniu zmiany te determinowały ich rozwój.

W tabeli 2 zawarte zostały dane wyjściowe użyte do analizy aktywów. Analiza majątku całkowitego wskazuje, iż w badanym okresie nastąpił wzrost jego wartości we wszystkich kategoriach przedsiębiorstw. Przeciętny stan aktywów wzrósł o 2050483 zł, z czego największy wzrost nastąpił w przedsiębiorstwach średnich (o 1789695 zł).

Tabela 2. Przeciętne wartości i udział aktywów bilansu badanych przedsiębiorstw w 2008 r. i w 2014 r.

\begin{tabular}{|c|c|c|c|c|c|c|}
\hline \multirow{2}{*}{ Wyszczególnienie } & \multicolumn{2}{|c|}{ Mikroprzedsiębiorstwa } & \multicolumn{2}{|c|}{ Małe przedsiębiorstwa } & \multicolumn{2}{|c|}{ Średnie przedsiębiorstwa } \\
\hline & $\begin{array}{c}\text { Wartość } \\
\text { [zł] }\end{array}$ & $\begin{array}{c}\text { udział } \\
\text { [\%] }\end{array}$ & $\begin{array}{c}\text { Wartość } \\
\text { [zł] }\end{array}$ & $\begin{array}{c}\text { udział } \\
\text { [\%] }\end{array}$ & $\begin{array}{c}\text { wartość } \\
\text { [zł] }\end{array}$ & $\begin{array}{c}\text { udział } \\
{[\%]}\end{array}$ \\
\hline \multicolumn{7}{|c|}{2008 rok } \\
\hline Aktywa trwałe & 254682 & 31,9 & 850459 & 31,6 & 6394347 & 49,4 \\
\hline Rzeczowe aktywa trwałe & 246150 & 30,8 & 777067 & 28,9 & 5238696 & 40,4 \\
\hline Środki transportu & 127916 & 16 & 252475 & 9,4 & 3694781 & 28,5 \\
\hline Należności długoterminowe & 32 & 0 & 0 & 0 & 12416 & 0,1 \\
\hline Inwestycje długoterminowe & 0 & 0 & 45253 & 1,7 & 1052347 & 8,1 \\
\hline Aktywa obrotowe & 543433 & 68,1 & 1840006 & 68,4 & 6557076 & 50,6 \\
\hline Należności krótkoterminowe & 330986 & 41,5 & 1388582 & 51,6 & 5111287 & 39,5 \\
\hline Inwestycje krótkoterminowe & 168301 & 21,1 & 244413 & 9,1 & 663392 & 5,1 \\
\hline Aktywa razem & 798130 & 100 & 2689481 & 100 & 12951423 & 100 \\
\hline \multicolumn{7}{|c|}{2014 rok } \\
\hline Aktywa trwałe & 212062 & 20,7 & 1578432 & 40,3 & 6857177 & 46,5 \\
\hline Rzeczowe aktywa trwałe & 211924 & 20,7 & 1346171 & 34,4 & 4970861 & 33,7 \\
\hline Środki transportu & 43916 & 4,3 & 510988 & 13 & 3676132 & 24,9 \\
\hline Należności długoterminowe & 0 & 0 & 75 & 0 & 736 & 0 \\
\hline Inwestycje długoterminowe & 0 & 0 & 135785 & 3,5 & 952160 & 6,5 \\
\hline Aktywa obrotowe & 812039 & 79,3 & 2338996 & 59,7 & 7883993 & 53,5 \\
\hline Należności krótkoterminowe & 557342 & 54,4 & 1559283 & 39,8 & 6329217 & 42,9 \\
\hline Inwestycje krótkoterminowe & 198019 & 19,3 & 425509 & 10,9 & 925487 & 6,3 \\
\hline Aktywa razem & 1024101 & 100,0 & 3917428 & 100,0 & 14741118 & 100,0 \\
\hline
\end{tabular}

Pierwszą część aktywów, która miała wpływ na sytuację majątkową badanych przedsiębiorstw, stanowiły aktywa trwałe. Ich wartość w 2014 r. wzrosła średnio, w stosunku do 2008 r. o prawie 13,3\%. Rzeczowe aktywa trwałe składały się w 2008 r. ze środków trwałych (83,5\%). Największą grupę w środkach trwałych w 2008 r. pod względem wartości stanowiły środki transportowe $(65,1 \%)$. 
Najwyższą średnią roczną dynamiką wzrostu wartości aktywów trwałych charakteryzowały się w badanym okresie małe przedsiębiorstwa. Wartość ich aktywów trwałych rosła w badanym okresie w średnim tempie wynoszącym 14,3\%. Z kolei mikroprzedsiębiorstwa zmniejszyły wartość swoich środków trwałych o 16,7\%.

Wzrost aktywów trwałych związany był głównie ze zwiększaniem się liczby użytkowanych przez przedsiębiorstwa pojazdów. Ich liczba wzrosła z 1879 w 2008 r. do 2900 w 2014 r. Jednocześnie w małych przedsiębiorstwach przyrost ten był największy - wyniósł 509 pojazdów w latach 2008-2014. Ogólna dynamika wartości środków trwałych w badanych podmiotach w ciągu 6-letniego okresu wynosiła $29,1 \%$, natomiast przyrost aktywów trwałych wynosił 58,4\%.

Ze względu na wielkość badanych firm najwyższą średnią roczną dynamiką wzrostu aktywów obrotowych charakteryzowały się mikroprzedsiębiorstwa. Wartość aktywów w ich przypadku rosła w badanym okresie w średnim tempie wynoszącym 134,4\%. Z kolei najmniejszą dynamikę wzrostu odnotowały przedsiębiorstwa średnie; wynosiła ona w badanym okresie 3,4\%, w związku z tym przedsiębiorstwa te zwiększyły wartość swojego majątku obrotowego jedynie o 970 tys. zł.

Aktywa obrotowe w 2008 r. stanowiły średnio 62,4\% aktywów, z czego w jednostkach mikro wynosiły one 68,1\%, w małych $-68,4 \%$, a w średnich - 50,6\%. W 2014 r. udział aktywów obrotowych w ogólnej liczbie badanych podmiotów spadł do 64,1\%. Największy odsetek aktywów obrotowych wykazywały przedsiębiorstwa mikro $(79,3 \%)$, najmniejszy przedsiębiorstwa średnie (53,5\%).

Największą część aktywów obrotowych w badanych podmiotach stanowiły należności krótkoterminowe, obejmujące wszystkie należności z tytułu dostaw i usług, niezależnie od terminu spłaty, oraz należności z innych tytułów niezaliczonych do aktywów finansowych, wymaganych w ciągu 12 miesięcy od dnia bilansowego. Udział należności krótkoterminowych w 2008 r. był najwyższy w firmach małych (75,5\% aktywów obrotowych). Z kolei w 2014 r. ich udział spadł w podmiotach mikro, natomiast wzrósł w podmiotach mikro i średnich. Jest to niekorzystna tendencja wskazująca, że jednostki te miały problem z uzyskiwaniem należności za wykonane usługi.

Zmianie uległa również wysokość środków finansowych, którymi dysponowały przedsiębiorstwa i które ujmowane były w inwestycjach krótkoterminowych (przyrost o 30,5\%). Wskazuje to na pozytywną tendencję, w badanym okresie. Niemniej znaczna część środków badanych przedsiębiorstw pozostawała zamrożona w postaci należności. Wynikało to głównie z terminów płatności w transporcie drogowym, które najczęściej wynoszą od 45 do 90 dni kalendarzowych. Jednocześnie brak wpływu należności za wykonane usługi w terminie przyczynia się do obniżenia płynności oraz elastyczności przedsiębiorstw.

Analiza aktywów nie może być oderwana od źródeł ich finansowania. Pasywa bilansu dają możliwość szczegółowej analizy sytuacji finansowej jednostki pod kątem jej kondycji, a także wpływu podejmowanych decyzji. Podstawowym składnikiem pasywów jest kapitał własny. Stanowią go wpłaty założycieli (właścicieli) oraz późniejsze wpłaty z zysku związane z jego podwyższeniem. Kapitał własny badanych przedsiębiorstw w 2008 r. wynosił dla jednostek mikro przeciętnie 234661 zł, dla firm małych był prawie 3-krotnie wyższy i osiągnął wartość 713754 zł. Przedsiębiorstwa średnie z kolei dysponowały przeciętnie kapitałem własnym na poziomie 3608595 zł. W 2014 r., w stosunku do 2008 r., 
w największym stopniu zwiększył się kapitał własny małych przedsiębiorstw (130,06\%). Średnie przedsiębiorstwa wykazały wzrost funduszu własnego na poziomie 22,7\%, natomiast mikroprzedsiębiorstwa zwiększyły swój kapitał o 18,9\% (tab. 3). Zmiany w obrębie funduszu własnego były związany głównie z przekazywaniem na jego rzecz nadwyżek finansowych osiąganych przez przedsiębiorstwa. Jednocześnie jego przyrost świadczy o umocnieniu pozycji badanych podmiotów w latach 2008-2014.

Tabela 3. Przeciętne wartości i udział pasywów bilansu badanych przedsiębiorstw w 2008 r. i 2014 r.

\begin{tabular}{|c|c|c|c|c|c|c|}
\hline \multirow[b]{2}{*}{ Wyszczególnienie } & \multicolumn{2}{|c|}{ Mikroprzedsiębiorstwa } & \multicolumn{2}{|c|}{ Małe przedsiębiorstwa } & \multicolumn{2}{|c|}{ Średnie przedsiębiorstwa } \\
\hline & $\begin{array}{c}\text { wartość } \\
\text { [zł] }\end{array}$ & $\begin{array}{l}\text { udział } \\
\text { (w \%) }\end{array}$ & $\begin{array}{c}\text { wartość } \\
\text { [zł] }\end{array}$ & $\begin{array}{l}\text { udział } \\
(\mathrm{w} \%)\end{array}$ & $\begin{array}{c}\text { wartość } \\
\text { [zł] }\end{array}$ & $\begin{array}{l}\text { udział } \\
\text { (w \%) }\end{array}$ \\
\hline \multicolumn{7}{|c|}{2008 rok } \\
\hline Kapitał (fundusz) własny & 234661 & 29,4 & 713754 & 26,5 & 3608595 & 27,9 \\
\hline Zysk (strata) netto & 9530 & 1,2 & 113392 & 4,2 & 157260 & 1,2 \\
\hline $\begin{array}{l}\text { Zobowiązania i rezerwy na } \\
\text { zobowiązania }\end{array}$ & 563469 & 70,6 & 1975726 & 73,5 & 9342828 & 72,1 \\
\hline Zobowiązania długoterminowe & 148224 & 18,6 & 329532 & 12,3 & 2817730 & 21,8 \\
\hline $\begin{array}{l}\text { Zobowiązania } \\
\text { krótkoterminowe }\end{array}$ & 411607 & 51,6 & 1617289 & 60,1 & 6302391 & 48,7 \\
\hline Pasywa razem & 798130 & 100,0 & 2689481 & 100,0 & 12951423 & 100,0 \\
\hline \multicolumn{7}{|c|}{2014 rok } \\
\hline Kapitał (fundusz) własny & 279209 & 27,3 & 1642063 & 41,9 & 4426626 & 30,0 \\
\hline Zysk (strata) netto & -36948 & $-3,6$ & 308644 & 7,9 & 1166485 & 7,9 \\
\hline $\begin{array}{l}\text { Zobowiązania i rezerwy na } \\
\text { zobowiązania }\end{array}$ & 744892 & 72,7 & 2275365 & 58,1 & 10314491 & 70,0 \\
\hline Zobowiązania długoterminowe & 64571 & 6,3 & 473432 & 12,1 & 2191579 & 14,9 \\
\hline $\begin{array}{l}\text { Zobowiązania } \\
\text { krótkoterminowe }\end{array}$ & 672234 & 65,6 & 1746060 & 44,6 & 7571315 & 51,4 \\
\hline Pasywa razem & 1024101 & 100,0 & 3917428 & 100,0 & 14741118 & 100,0 \\
\hline
\end{tabular}

W badanym okresie zmianom podlegała również struktura pasywów. W 2008 r. udział kapitału własnego w pasywach wynosił $29,4 \%$ w mikro, 26,5\% w małych i 27,9\% w średnich przedsiębiorstwach. Z kolei w 2014 r. w jednostkach małych udział kapitału własnego wzrósł o 15,4 pp., w przedsiębiorstwach średnich - o 2,1 pp., natomiast w mikroprzedsiębiorstwach nastąpił jego spadek o 1,7 pp. Obniżenie udziału kapitału własnego powodowało pogorszenie niezależności finansowej najmniejszych podmiotów w stosunku do roku 2008. Tym samym przedsiębiorstwa musiały w większym stopniu korzystać z zewnętrznych źródeł finansowania.

$\mathrm{Na}$ sytuację przedsiębiorstwa, a także na stan jego kapitału własnego w znacznym stopniu wpływa generowany zysk, który może być przeznaczany na zwiększanie rezerwy finansowej lub inwestycje. Przeciętny zysk osiągany przez jednostki mikro w 2008 r. wynosił 9350 zł. Podmioty małe osiągnęły zysk w wysokości 113392 zł, natomiast przedsiębiorstwa średnie - 157260 zł. W 2014 r. mikroprzedsiębiorstwa wykazywały stratę w wysokości 36948 zł, małe i średnie przedsiębiorstwa - natomiast zysk, który wynosił odpowiednio 308644 zł i 1166485 zł. Oznacza to wyraźną poprawę sytuacji finansowej dwóch wyżej wskazanych grup przedsiębiorstw. Jednocześnie nastąpiło wyraźne pogorszenie sytuacji finansowej mikroprzedsiębiorstw. Należy jednak wyniki te interpretować z dużą ostrożnością, ponieważ poniesione straty były w dużym stopniu związane $z$ inwestycjami w nowy tabor, co nastąpiło w szczególności w latach 2011-2014. 
W badanym okresie we wszystkich kategoriach przedsiębiorstw dominowały zobowiązania krótkoterminowe. Zarówno w mikroprzedsiębiorstwach, jak i w średnich udział ten uległ zwiększeniu w 2014 r., w stosunku do 2008 r. (odpowiednio o 14,0\% oraz o 2,7\%). Jest to na ogół niepokojąca tendencja, ponieważ zbyt duże obciążenie pasywów tego typu zobowiązaniami może prowadzić do kłopotów z płynnością finansową i generować dodatkowe koszty wynikające z odsetek. Główną część zobowiązań krótkoterminowych stanowiły zobowiązania z tytułu podatków, ceł, ubezpieczeń społecznych oraz z tytułu dostaw i usług. Wskazuje to na przejściowe problemy badanych podmiotów z ich terminowym regulowaniem. Jest to sytuacja niekorzystna, ponieważ naraża przedsiębiorstwo na dodatkowe koszty związane z karami finansowymi oraz z dochodzeniem roszczeń od wierzycieli.

Z kolei wynik finansowy netto badanej grupy przedsiębiorstw w latach 2008-2011 wykazywał tendencję wzrostową. Sytuacja ta zmieniła się w 2012 r., w którym przeciętny zysk osiągany przez badane przedsiębiorstwa spadł o 134 tys. zł, a także wzrosło zadłużenie przedsiębiorstw. Było to spowodowane w dużym stopniu inwestycjami w tabor samochodowy. Zysk od 2013 r. w grupie badanych podmiotów ponownie zaczął wzrastać, co wskazuje, że pogorszenie wyników finansowych w 2012 r. było jedynie przejściowe.

Efektywność wykorzystywanego majątku oznacza zysk netto przypadający na jednego zatrudnionego oraz, w przypadku podmiotów transportowych, na jeden pojazd. Pozwala on ocenić, ile zysku przeciętnie zostało wypracowanego przez jedną pracującą osobę oraz przez jeden pojazd. W 2008 r. jeden zatrudniony wypracował przeciętnie 2750,58 zł zysku, w 2014 r. natomiast wypracowany zysk wynosił już 10 855,57 zł. Natomiast wzrost przeciętnego zysku na jeden pojazd w 2014 r., w stosunku do 2008 r., wzrósł o 18 174,29 zł (z 7895 zł w 2008 r. do 26069 zł w 2014 r.). Badany okres tym samym charakteryzował się wzrostem ogólnej wydajności pracy, która jest jednym z podstawowych czynników wpływających na rozwój przedsiębiorstwa.

W latach 2008-2014 rosły także przychody osiągane przez badane przedsiębiorstwa. W 2008 r. ich przeciętna roczna wartość wynosiła 6842 tys. zł, po 6 latach natomiast ich wartość wzrosła do 10157 tys. zł. Najniższy poziom przychodów ze sprzedały zanotowano w przedsiębiorstwach mikro (średnio 5889,31 tys. zł na firmę), a najwyższy - w grupie przedsiębiorstw średnich (średnio 31 070,41 tys. zł). Największą dynamiką ich wzrostu charakteryzowały się przedsiębiorstwa mikro, gdzie w latach 2008-2014 średnia roczna dynamika wzrostu przychodów w badanej grupie wyniosła 38,2\%; najwyższą dynamikę wykazały firmy małe $(8,1 \%)$, a najniższą $(2,4 \%$,) odnotowano w grupie podmiotów średnich, zatrudniających powyżej 50 pracowników

Kolejnym etapem pracy była ocena finansowa małych i średnich przedsiębiorstw, na podstawie analizy wskaźnikowej. Jest ona cennym narzędziem wspomagającym proces zarządzania przedsiębiorstwem oraz wykorzystywanym przez instytucje finansowe do oceny jego sytuacji finansowej. Analiza wskaźnikowa stanowi część analizy ekonomicznej, będącą rozwinięciem analizy wstępnej sprawozdań finansowych.

Wartości poszczególnych wskaźników dla ogółu badanych przedsiębiorstw sektora transportu drogowego zostały przedstawiono w tab. 4. Pierwszym wskaźnikiem, który został poddany badaniu w grupie analizowanych podmiotów, był wskaźnik unieruchomienia majątku. Wskaźnik ten stanowi relację aktywów trwałych do aktywów obrotowych. Jeżeli 
wartość wskaźnika kształtuje się powyżej 1, świadczy to przewadze aktywów trwałych nad aktywami obrotowymi w przedsiębiorstwie. Wynik ten na ogół interpretuje się negatywnie (Sierpińska i Jachna 2004).

W badanych przedsiębiorstwach transportowych wskaźnik ten kształtował się na poziomie niższym od 1, co związane jest z większym udziałem płynnych aktywów obrotowych w majątku całkowitym. Największą wartość wskaźnik osiągnął w 2012 r. i 2013 r. $(0,8)$, natomiast jego średnia wartość dla całego okresu badawczego wyniosła 0,7 (tab. 4). Zarówno w mikroprzedsiębiorstwach, małych, jak i średnich poziom wskaźnika unieruchomienia majątku utrzymywał się na stałym poziomie, z niewielkimi wahaniami. Najmniej korzystna była sytuacja w małych przedsiębiorstwach w 2009 r., gdy wskaźnik wzrósł powyżej 1.

Tabela 4. Wartości poszczególnych wskaźników finansowych i majątkowych dla badanych podmiotów w latach 2008-2014

\begin{tabular}{|l|r|r|r|r|r|r|r|}
\hline \multicolumn{1}{|c|}{ Wyszczególnione } & 2008 & 2009 & 2010 & 2011 & 2012 & 2013 & 2014 \\
\hline Wskaźnik unieruchomienia majątku & 0,6 & 0,6 & 0,6 & 0,6 & 0,8 & 0,7 & 0,8 \\
\hline $\begin{array}{l}\text { Wskaźnik udziału majątku trwałego } \\
\text { W aktywach całkowitych }\end{array}$ & 33,6 & 31,6 & 31,7 & 30,8 & 33,2 & 35,2 & 34,0 \\
\hline $\begin{array}{l}\text { Wskaźnik udziału majątku obrotowego } \\
\text { W aktywach całkowitych }\end{array}$ & 60,9 & 63 & 61,8 & 60,8 & 54,8 & 59,1 & 56,5 \\
\hline Wskaźnik produktywności aktywów & 347,6 & 366,2 & 551,2 & 700 & 486,2 & 469,5 & 492,3 \\
\hline $\begin{array}{l}\text { Wskaźnik udziału kapitałów własnych } \\
\text { w finansowaniu majątku trwałego }\end{array}$ & 33,8 & 24,1 & 27,8 & 21,4 & 25,8 & 17,3 & 21,2 \\
\hline ROE & 1,8 & 4,1 & 6,4 & 5,0 & 2,5 & 6,1 & 1,8 \\
\hline ROA & 6,6 & 14,2 & 18,8 & 16,1 & 8,2 & 17,4 & 6,6 \\
\hline ROS & 0,7 & 1,7 & 2,5 & 2,0 & 1,1 & 2,4 & 0,7 \\
\hline DR (ogólne zadłużenie) & 1,58 & 2,03 & 2,21 & 1,9 & 1,52 & 2,67 & 2,89 \\
\hline CR (wskaźnik płynności bieżącej) & 72,0 & 71,4 & 65,7 & 68,6 & 69,9 & 65,1 & 63,5 \\
\hline Marża brutto & 112,1 & 119,0 & 117,8 & 103,3 & 111,0 & 116,7 & 112,5 \\
\hline Zadłużenie kapitału własnego & 258,2 & 250,2 & 191,7 & 218,2 & 232,8 & 186,4 & 174,1 \\
\hline Wskaźnik zadłużenia długoterminowego & 58,8 & 59,0 & 40,7 & 44,9 & 72,0 & 42,3 & 36,6 \\
\hline
\end{tabular}

Wskaźnik udziału majątku trwałego w majątku całkowitym jest głównym wskaźnikiem struktury majątku. Większa wartość tego wskaźnika oznacza mniejszą elastyczność przedsiębiorstwa na zmiany koniunktury gospodarczej i - co za tym idzie - wyższe ryzyko prowadzenia działalności (Rybicki 2004).

W badanych przedsiębiorstwach wskaźnik udziału majątku trwałego w majątku całkowitym wykazywał zróżnicowane wartości w poszczególnych okresach sprawozdawczych, jednocześnie utrzymywał się na poziomie mniejszym niż 40,0, przy czym największą wartość odnotowano w 2013 r. (35,2), a najmniejszą - w 2011 r. (30,8). Najbardziej korzystną wartość wskaźnika w badanym okresie wykazywały przedsiębiorstwa małe, w których jego wartość była najmniejsza (tab. 5).

Najmniejszą przeciętną wartość wskaźnika udziału majątku trwałego w aktywach całkowitych osiągnęły mikroprzedsiębiorstwa $(20,7)$, natomiast największą - jednostki średnie $(40,4)$. Wynika to przede wszystkim z większych zasobów w majątku trwałym 
większych jednostek i z tego względu z ich mniejszej elastyczności. Związane to było głównie z większą liczbą pojazdów będących własnością tej kategorii przedsiębiorstw. Mikroprzedsiębiorstwa natomiast w mniejszym stopniu dysponowały własnymi środkami transportu, korzystając częściej z leasingu.

Tabela 5. Wartości poszczególnych wskaźników finansowych i majątkowych dla badanych małych przedsiębiorstw w latach 2008-2014

\begin{tabular}{|l|r|r|r|r|r|r|r|}
\hline \multicolumn{1}{|c|}{ Wyszczególnione } & 2008 & 2009 & 2010 & 2011 & 2012 & 2013 & 2014 \\
\hline Wskaźnik unieruchomienia majątku & 0,5 & 0,5 & 0,5 & 0,6 & 0,6 & 0,6 & 0,7 \\
\hline $\begin{array}{l}\text { Wskaźnik udziału majątku trwałego } \\
\text { w aktywach całkowitych }\end{array}$ & 28,0 & 27,8 & 30,2 & 32,4 & 30,0 & 33,1 & 33,6 \\
\hline $\begin{array}{l}\text { Wskaźnik udziału majątku obrotowego } \\
\text { w aktywach całkowitych }\end{array}$ & 69,0 & 68,7 & 66,1 & 61,0 & 62,7 & 62,6 & 60,4 \\
\hline Wskaźnik produktywności aktywów & 437,4 & 429,6 & 615,8 & 830,3 & 580,3 & 568,3 & 628,6 \\
\hline $\begin{array}{l}\text { Wskaźnik udziału kapitałów własnych } \\
\text { w finansowaniu majątku trwałego }\end{array}$ & 35,6 & 27,6 & 27,3 & 26,1 & 25,8 & 17,4 & 26,0 \\
\hline ROE & 16,2 & 15,9 & 15,3 & 16,2 & 11,7 & 18,2 & 16,2 \\
\hline ROA & 4,5 & 4,2 & 5,5 & 6,0 & 4,8 & 7,7 & 4,5 \\
\hline ROS & 1,6 & 1,6 & 1,9 & 2,0 & 1,4 & 2,3 & 1,6 \\
\hline DR (ogólne zadłużenie) & 72,1 & 73,7 & 63,8 & 62,9 & 58,9 & 57,9 & 58,2 \\
\hline CR (wskaźnik płynności bieżącej) & 115,8 & 117,1 & 123,1 & 107,9 & 135,3 & 143,6 & 134,8 \\
\hline Marża brutto & 0,99 & 2,24 & 3,03 & 2,18 & 1,87 & 2,67 & 2,37 \\
\hline Zadłużenie kapitału własnego & 259,8 & 281,1 & 175,9 & 169,5 & 143,5 & 137,8 & 139,5 \\
\hline Wskaźnik zadłużenia długoterminowego & 41,8 & 53,1 & 33,9 & 42,5 & 28,1 & 29,6 & 29,2 \\
\hline
\end{tabular}

Kolejnym badanym wskaźnikiem był wskaźnik udziału majątku obrotowego w aktywach całkowitych, szacowany jako stosunek aktywów obrotowych do aktywów ogółem. Większa wartość tego wskaźnika informuje o bardziej elastycznym profilu prowadzonej działalności gospodarczej i - co za tym idzie - o łatwiejszej i szybszej zmianie branży czy specjalizacji (Gabrusewicz 2014).

W badanej grupie widoczny jest wzrost jego wartości w 2010 r. i 2013 r. Najmniejszą przeciętną wartość wskaźnika w latach 2008-2014 wykazywały średnie przedsiębiorstwa (przeciętnie 63,9), z kolei największą - jednostki mikro (przeciętnie 65,1) - tab. 6. Dokonując ogólnej analizy oszacowanych wartości, można stwierdzić, że badane podmioty na ogół miały korzystną strukturę majątkową pod względem proporcji majątku trwałego i obrotowego.

W ocenie efektywności gospodarowanym majątkiem całkowitym najczęściej wykorzystywany jest wskaźnik produktywności aktywów. Wzrost wartości tego wskaźnika, w porównaniu z poprzednimi latami działalności przedsiębiorstwa, oznacza pożądany wzrost produkcji na jednostkę majątku (Nowak 2017).

W badanych przedsiębiorstwach w latach 2008-2011 wskaźnik ten wykazywał tendencję wzrostową. W 2008 r. produktywność majątku kształtowała się na poziomie 347,6, natomiast w 2010 r. wartość ta wzrosła do 700,0. W kolejnych okresach następował spadek wskaźnika, związany w obniżeniem produktywności majątków badanych podmiotów. Najwyższą produktywność majątku w badanym okresie wykazywały podmioty małe (średnia wartość wskaźnika - 584,3) oraz średnie $(309,2)$ - tab. 7. Wynika to z większych zasobów majątkowych, a tym z samym lepszej pozycji rynkowej większych jednostek, w stosunku do mikroprzedsiębiorstw. 
Tabela 6. Wartości poszczególnych wskaźników finansowych i majątkowych dla badanych mikroprzedsiębiorstw w latach 2008-2014

\begin{tabular}{|l|r|r|r|r|r|r|r|}
\hline \multicolumn{1}{|c|}{ Wyszczególnione } & 2008 & \multicolumn{1}{|c|}{2009} & 2010 & \multicolumn{1}{c|}{2011} & 2012 & \multicolumn{1}{c|}{2013} & 2014 \\
\hline Wskaźnik unieruchomienia majątku & 0,5 & 1,0 & 0,6 & 0,4 & 0,7 & 0,6 & 0,3 \\
\hline $\begin{array}{l}\text { Wskaźnik udziału majątku trwałego } \\
\text { w aktywach całkowitych }\end{array}$ & 30,8 & 47,2 & 36,4 & 28,3 & 39,5 & 35,6 & 20,7 \\
\hline $\begin{array}{l}\text { Wskaźnik udziału majątku obrotowego } \\
\text { w aktywach całkowitych }\end{array}$ & 68,1 & 51,1 & 61,8 & 70,6 & 60,5 & 64,4 & 79,3 \\
\hline Wskaźnik produktywności aktywów & 263,9 & 287,2 & 319,4 & 312,6 & 235,3 & 240,7 & 160,7 \\
\hline $\begin{array}{l}\text { Wskaźnik udziału kapitałów własnych } \\
\text { W finansowaniu majątku trwałego }\end{array}$ & 42,4 & 16,1 & 18,4 & 18,0 & 33,5 & 18,6 & 12,8 \\
\hline ROE & 4,1 & 2,2 & $-6,8$ & 6,5 & 18,1 & 4,9 & 4,1 \\
\hline ROA & 1,2 & 1,1 & $-2,4$ & 2,0 & 4,8 & 1,6 & 1,2 \\
\hline ROS & 0,5 & 0,4 & $-0,3$ & 0,2 & 0,5 & 0,2 & 0,5 \\
\hline DR (ogólne zadłużenie) & 70,6 & 51,7 & 64,3 & 68,9 & 73,5 & 68,0 & 72,7 \\
\hline CR (wskaźnik płynności bieżącej) & 132,0 & 104,9 & 130,5 & 114,2 & 102,2 & 117,7 & 120,8 \\
\hline Marża brutto & 4,21 & 2,90 & 1,07 & 4,16 & 2,39 & 2,60 & 3,95 \\
\hline Zadłużenie kapitału własnego & 240,1 & 106,9 & 186,6 & 221,8 & 277,8 & 212,7 & 266,8 \\
\hline Wskaźnik zadłużenia długoterminowego & 63,2 & 5,5 & 48,9 & 22,6 & 52,5 & 37,6 & 23,1 \\
\hline
\end{tabular}

Tabela 7. Wartości poszczególnych wskaźników finansowych i majątkowych dla badanych średnich przedsiębiorstw w latach 2008-2014

\begin{tabular}{|l|r|r|r|r|r|r|r|}
\hline \multicolumn{1}{|c|}{ Wyszczególnione } & 2008 & 2009 & 2010 & 2011 & 2012 & 2013 & 2014 \\
\hline Wskaźnik unieruchomienia majątku & 1,0 & 0,8 & 0,8 & 0,7 & 1,1 & 0,8 & 0,9 \\
\hline $\begin{array}{l}\text { Wskaźnik udziału majątku trwałego } \\
\text { w aktywach całkowitych }\end{array}$ & 40,4 & 35,3 & 36 & 28,6 & 35,5 & 37,2 & 34,9 \\
\hline $\begin{array}{l}\text { Wskaźnik udziału majątku obrotowego } \\
\text { w aktywach całkowitych }\end{array}$ & 50,6 & 56,1 & 54,5 & 60,3 & 48,5 & 55,4 & 52,0 \\
\hline Wskaźnik produktywności aktywów & 277,4 & 311,5 & 359,7 & 336,5 & 252 & 316,2 & 309,9 \\
\hline $\begin{array}{l}\text { Wskaźnik udziału kapitałów własnych } \\
\text { w finansowaniu majątku trwałego }\end{array}$ & 30,3 & 27,7 & 40 & 25,1 & 21,5 & 17,9 & 26,9 \\
\hline ROE & 1,2 & 4,2 & 6,6 & 3,9 & 0,6 & 4,8 & 1,2 \\
\hline ROA & 4,4 & 14 & 18 & 16,2 & 2,7 & 16,9 & 4,4 \\
\hline ROS & 0,6 & 1,7 & 2,7 & 1,6 & 0,3 & 2,1 & 0,6 \\
\hline DR (ogólne zadłużenie) & 0,48 & 1,59 & 1,27 & 0,5 & 0,43 & 2,7 & 3,17 \\
\hline CR (wskaźnik płynności bieżącej) & 72,1 & 70,1 & 63,3 & 76,2 & 78,4 & 71,9 & 68,3 \\
\hline Marża brutto & 104,0 & 123,8 & 123 & 97,4 & 94,4 & 96,8 & 94,6 \\
\hline Zadłużenie kapitału własnego & 258,9 & 234,9 & 172,6 & 320,3 & 362,5 & 255,6 & 215,3 \\
\hline Wskaźnik zadłużenia długoterminowego & 78,1 & 74,6 & 47,5 & 50,8 & 137 & 60,9 & 46,3 \\
\hline
\end{tabular}

Wskaźnik udziału kapitału własnego w finansowaniu majątku stanowi kolejny element oceny sytuacji majątkowej przedsiębiorstwa. Tendencja wzrostowa tego wskaźnika oznacza pozytywny kierunek rozwoju przedsiębiorstwa, gdyż ryzyko działalności się zmniejsza. Niższy poziom będzie natomiast świadczył o malejącym udziale kapitałów własnych w finansowaniu działalności gospodarczej przedsiębiorstwa, a tym samym o wzroście ryzyka (Siudek 2004).

W badanym okresie wskaźnik wykazywał tendencję spadkową, przyjmując w 2008 r. wartość 33,8, natomiast w 2014 r. - wartość 21,2. Spadek jego wartości zauważalny jest szczególnie od 2011 r. Należy to postrzegać jako zjawisko negatywne, ponieważ związane było z obniżeniem niezależności finansowej przedsiębiorstw i pogorszeniem zabezpieczenia 
spłaty zadłużenia posiadanymi aktywami (tzw. zmniejszeniem pojemności zadłużeniowej). Głównym powodem tego stanu był wspomniany wcześniej wzrost wielkości wykorzystywanego taboru. Wskaźnik udziału kapitału własnego w finansowaniu majątku najbardziej się zmniejszył w mikroprzedsiębiorstwach, natomiast w najmniej - w jednostkach średnich.

Kolejnym etapem badania była analiza wskaźników finansowych, która pozwala w sposób syntetyczny dokonać diagnozy sytuacji jednostki lub grupy jednostek wybranym okresie. Podstawową grupą wskaźników służących do oceny sytuacji są wskaźniki rentowności, płynności oraz zadłużenia. Uważane są one za najbardziej syntetyczne mierniki ewaluacji działalności firmy. $\mathrm{Na}$ ich poziom wpływa całokształt zjawisk gospodarczych zachodzących w firmie (Czekaj i Dresler 2011).

Wskaźnik ROA (wskaźnik rentowności aktywów) stanowi stopę zwrotu z aktywów, informując o tym, jaka jest rentowność wszystkich aktywów firmy w stosunku do wypracowanych przez nią zysków. Wskaźnik ten jest istotny w przypadku przedsiębiorstw transportowych, ponieważ pozwala zdiagnozować, czy tabor zakupiony zarówno z finansowania zewnętrznego, jak i wewnętrznego jest wykorzystywany w optymalny sposób do wypracowywania zysku.

W badanych podmiotach sektora transportu drogowego w województwie zachodniopomorskim wskaźnik ROA w 2008 r. wynosił 1,8, a następnie zaczął wzrastać, osiągając największą wartość w 2010 r. Następnie produktywność aktywów zaczęła maleć i ponownie wykazywać wzrost w 2013 r. Przyjmuje się, że im większą wartość ma wskaźnik, tym lepsza jest kondycja finansowa przedsiębiorstwa. W ujęciu według kategorii przedsiębiorstw największą wartość ROA wykazywały przedsiębiorstwa małe oraz średnie, natomiast najmniejszą - mikroprzedsiębiorstwa. Oznacza to, że małe podmioty najmniej efektywnie wykorzystywały swój majątek rzeczowy. Wynikało to głównie z ich słabszej pozycji rynkowej, co skutkowało mniejszymi możliwościami zdobywania lepszych zleceń przewozowych.

Uzupełnieniem wskaźnika ROA jest wskaźnik ROE, który służy ocenie rentowności kapitału własnego. Wyższa efektywność kapitału własnego wiąże się z możliwością uzyskania wyższej nadwyżki finansowej. Rozwijające się przedsiębiorstwa powinny gwarantować wyższy zysk dla właścicieli z zaangażowanych środków. Jednocześnie przekłada się to na większą stabilność finansową, a tym samym - na bezpieczeństwo kontrahentów i instytucji finansowych.

W badanym okresie większość badanych podmiotów wykazywał wartość tego wskaźnika na wysokim poziomie. Maksymalny poziom wskaźnika został osiągnięty w 2010 r. $(18,8)$, natomiast minimalny - w 2008 r. i 2014 r. Jednocześnie wskaźnik ten wykazywał tendencję wzrostową od 2008 r. do 2010 r. W kolejnych okresach wartość wskaźnika ulegała zmianom. Ze względu na klasę wielkości najkorzystniejsze wartości wskaźnika wykazywały podmioty małe, natomiast w przypadku mikroprzedsiębiorstw były one najmniejsze. Z kolei średnie przedsiębiorstwa charakteryzowały się wyraźnymi wahaniami wskaźnika ROE w poszczególnych okresach. Ujemne wartości wskaźnika ROA dla podmiotów mikro świadczyły o ujemnej wartości kapitałów własnych. W takiej sytuacji bez dokapitalizowania ich istnienie było zagrożone. Na ujemną wartość kapitałów własnych w badanych podmiotach najczęściej wpływała strata z lat ubiegłych, co jednocześnie miało charakter krótkookresowy i co należy interpretować jako przejściowe problemy finansowe. 
Do oceny rentowności sprzedaży wykorzystuje się, w ramach analizy wskaźnikowej, najczęściej wskaźnik ROS. Wskaźnik ten informuje także, jaką marżę zysku przynosi sprzedaż usług transportowych. Im większa jest wartość tego wskaźnika, tym mniejsza wartość sprzedaży, która pozwala osiągnąć zysk, co świadczy o lepszej sytuacji przedsiębiorstwa.

W przypadku badanych podmiotów wskaźnik ROS wykazywał podobną tendencję jak przedstawione wyżej wskaźniki - wzrastał on od 2009 r., osiągając wartość maksymalną w 2010 r., a w kolejnych okresach do 2013 r. ponownie wykazywał tendencję spadkową Analogicznie jak w przypadku wskaźnika ROA najlepsze parametry w badanym okresie, najwyższą rentowność sprzedaży osiągały podmioty małe i średnie, natomiast najniższą jednostki mikro. Wysokie koszty ponoszone przez przedsiębiorstwa obniżały osiągane efekty finansowe, a jednocześnie następowała okresowa poprawa związana głównie ze zmianami cen paliwa oraz stóp procentowych. Nie zauważono jednak w jakimkolwiek przedsiębiorstwie długotrwałej zmiany wskaźnika ROS, co wiązałoby się z zastosowaniem optymalizacji kosztów.

Miernik marży brutto stanowi uzupełnienie wyżej omawianego wskaźnika ROS. Wskaźnik ten informuje, ile procent przychodów ze sprzedaży stanowi zysk brutto. W badanych podmiotach wskaźnik marży brutto utrzymywał się w latach 2008-2014 na poziomie przeciętnym (2,1\%), z czego najwyższy jego poziom odnotowały przedsiębiorstwa mikro $(3,1 \%)$. W przedsiębiorstwach małych i średnich wskaźnik ten był dodatni, co również wskazywało na ich poprawną sytuację finansową. Wartości marży brutto rosły w dwóch podokresach badania, tj. od 2009 do 2010 r. oraz od 2012 do 2013 r. Wpływ na to miało głownie otwarcie możliwości wykonywania przewozów kabotażowych od 2009 r.

Kolejnym analizowanym wskaźnikiem finansowy był wskaźnik DR (wskaźnik ogólnego zadłużenia), który określa udział źródeł obcych w finansowaniu aktywów przedsiębiorstwa, wyrażonych w wartości bilansowej. Przyjmuje się, że jego wartość powinna oscylować w przedziale 57-67\%. (Stefanko i Łącka 2017). W przypadku podmiotów transportowych może służyć on zarówno do oceny ryzyka przez banki, związanego z udzielaniem kredytów i leasingów na zakup nowych środków transportowych, jak i ryzyka ponoszonego przez potencjalnych kontrahentów przedsiębiorstwa.

W badanej grupie wartość wskaźnika DR wskazuje na duży udział kapitałów obcych, którymi przedsiębiorstwa finansowały swój wzrost (głównie wykorzystywanego taboru). Poprzez cały 6-letni okres badawczy stopa zadłużenia utrzymywała się na poziomie powyżej $67,0 \%$. Takie wyniki świadczą o tym, że w tym czasie występowało nadmierne ryzyko kredytowe. Duży udział kapitałów obcych związany był w znacznym stopniu z formami finansowania majątku, takimi jak leasing czy kredyty, które były powszechnie wykorzystywane przez badane podmioty transportowe.

Przewoźnicy drogowi, którzy chcą konkurować na rynku, muszą charakteryzować się wysoką płynnością. Do jej określenia powszechnie wykorzystuje się miernik CR (wskaźnik płynności bieżącej), który informuje o potencjalnej zdolności do spłaty bieżących zobowiązań za pomocą krótkoterminowych aktywów. Za właściwą przyjmuje się sytuację, gdy jego wartość będzie większa od 100 .

W przypadku badanych przedsiębiorstw wartość wskaźnika CR wynosiła średnio 113,2\%, Szczególnie niepokojącą wartość wskaźnika notowano w średnich przedsiębiorstwach w 2011 r. spadła poniżej 100\%. W takim wypadku należy stwierdzić, że ta kategoria badanych podmiotów w latach 2011-2014 miała problemy z regulowaniem bieżących zobowiązań. Natomiast najlepszą płynnością charakteryzowały się przedsiębiorstwa małe, dla których wskaźnik CR wynosił średnio 125,3\%. 
Rozwój przedsiębiorstwa powinien być skorelowany także z jego stabilnością finansową. Do oceny wielkości kapitałów obcych biorących udział w finansowaniu przedsiębiorstwa, wobec kapitałów własnych, stosuje się wskaźnik zadłużenia kapitału własnego. Badane przedsiębiorstwa sektora transportowego w województwie zachodniopomorskim, jak już wspomniano, charakteryzowały się częstym wykorzystywaniem zewnętrznych źródeł finansowania w szczególności inwestycji w środki trwałe. Duża wartość wskaźnika (na poziomie powyżej $200,0 \%$ ) wskazuje, że zobowiązania ogółem były większe od kapitałów własnych prawie 2-krotnie. W przypadku przedsiębiorstw średnich wskaźnik ten wyniósł w 2011 r. i 2012 r. ponad 300\%, co oznacza, że zobowiązania były aż 3-krotnie większe od kapitałów własnych.

Duża wartość wskaźnika była niepokojącą oznaką dużego zadłużenia badanych jednostek. Należy jednak stwierdzić, że zadłużenie to wykazywało tendencję spadkową pod koniec analizowanego okresu, można je więc traktować jako sytuację przejściową, szczególnie w latach 2011-2012, gdy przewoźnicy dużo inwestowali w tabor, wykorzystując w tym celu finansowanie zewnętrzne.

Analiza zadłużenia jednostki powinna być prowadzona również na podstawie o zobowiązań długoterminowych. Do oceny zadłużenia o stosunkowo długim terminie wymagalności wykorzystuje się wskaźnik zadłużenia długoterminowego. W analizowanych podmiotach zadłużenie długoterminowe było na zadowalającym poziomie i jednocześnie wykazywało trend spadkowy.

Z wyjątkiem 2012 r. otrzymany wskaźnik znajdował się w przedziale poniżej 50\%. Jednocześnie jedynie w tym roku jego wartość dla przedsiębiorstw średnich znajdowała się powyżej granicy $100 \%$. Choć w latach 2008-2014 rósł poziom ogólnego zadłużenia badanych podmiotów, to zobowiązania długoterminowe nie stanowiły jego znacznej części.

\section{WNIOSKI}

Rozwój przedsiębiorstwa odbywa się zarówno w kontekście jego rozwoju wewnętrznego, jak i zewnętrznego. Niemniej wewnętrzna stabilizacja przedsiębiorstwa warunkuje sukces w jego otoczeniu. Analiza danych finansowych, odzwierciedlająca wewnętrzne uwarunkowania rozwojowe badanych przedsiębiorstw, pozwala wskazać czynniki, które w latach 2008-2014 decydowały o rozwoju badanych podmiotów.

W badanym okresie następował ogólny wzrost badanych podmiotów, objawiający się zwiększeniem kapitałów własnych, majątku oraz zysku. Najgorzej radziły sobie mikroprzedsiębiorstwa, które charakteryzowały się także najniższą stabilnością finansową. Rozwój badanych podmiotów związany był ze wzrostem ogólnego poziomu zadłużenia. Wskazuje to na powszechne wykorzystywanie przez przewoźników mechanizmu dźwigni finansowej w celu zwiększenia majątku, w tym głównie taboru. Świadczy to również o rosnącym popycie na usługi transportowe w latach 2008-2014. W przypadku gdyby zapotrzebowanie na przewozy, wykonywane przez przedsiębiorstwa transportowe, nie wzrastało, badane przedsiębiorstwa z pewnością nie zwiększałyby liczby wykorzystywanych pojazdów.

Wartość wskaźnika zadłużenia utrzymywała się w grupie małych i średnich przedsiębiorstw na wysokim poziomie. Uzyskane wartości wynikały głównie z powszechnego wykorzystywania kredytu oraz leasingu jako podstawowych form finansowania majątku, w tym głównie floty pojazdów. 
Większą wartość od przeciętnej wykazywał również wskaźnik udziału kapitałów własnych w finansowaniu majątku trwałego. Wysoki udział obcych źródeł finansowania powodował przyrost kosztów, które powodowały dodatkowe obciążenie przedsiębiorstw. Prowadziło to do obniżenia zysku, który w wielu podmiotach był niewystarczający do finansowania rozwoju z własnych środków. Na wybór zewnętrznego finansowania taboru w znacznym stopniu wpływały również malejące w latach 2008-2014 stopy procentowe, które obniżały koszty leasingów i kredytów.

Wartości wskaźników ROE i ROA w badanych przedsiębiorstwach były na zadowalającym poziomie. W latach 2008-2014 widoczny był wzrost udziału kapitału własnego w pasywach ogółem w małych i średnich przedsiębiorstwach, przy czym największy przyrost notowany był w jednostkach małych, w których jego udział wzrósł o 15,4 pp. O wzroście kapitału własnego decydowały przyrosty zysku przedsiębiorstwa. Zysk ten w badanym okresie wykazywał wahania, ale nie wykazywał ciągłej tendencji wzrostowej. Jednak podstawowym problemem analizowanych podmiotów był w dalszym ciągu niedostateczny zasób funduszów własnych.

Ogólna zyskowność sprzedaży usług transportowych badanych przedsiębiorstw była na stosunkowo niskim poziomie. Wartości wskaźnika ROS w poszczególnych latach były małe. Przeciętna marża brutto wynosiła w badanym okresie 2,0\% i była najwyższa w grupie przedsiębiorstw średnich. Na niską zyskowność wpływały, poza wyżej wskazanymi czynnikami, głównie duża konkurencja oraz związane z nią stosunkowo niskie stawki przewozowe na rynku transportowym. Badane podmioty miały również problem z zachowaniem płynności bieżącej związanej ze zdolnością bieżącego regulowania zobowiązań. Niska płynność była efektem stosunkowo długich terminów zapłaty za wykonane usługi transportowe.

Niskie zasoby kapitału własnego obniżały płynność szczególnie w grupie przedsiębiorstw mikro. Odzwierciedleniem problemów płatniczych był wzrost zarówno należności krótko- jak i długoterminowych. Brak terminowych płatności za wykonane usługi powodował, że przedsiębiorstwa musiały pokryć we własnym zakresie koszty wynagrodzeń i zużytych materiałów. Ponadto wzrost przedsiębiorstw był finansowany głównie poprzez zaciąganie zobowiązań finansowych, co skutkowało wzrostem ogólnego zadłużenia. Niemniej dokonując podsumowania, na podstawie przeanalizowanych danych finansowych, można stwierdzić, że w latach 2008-2014 nastąpił intensywny rozwój badanych podmiotów. Jednak był on w znacznym stopniu finansowany na kredyt. W takiej sytuacji, w przypadku pogorszenia się sytuacji rynkowej objawiającej się spadkiem popytu na usługi transportowe, firmy te mogą mieć problem z wypłacalnością, a tym samym ich istnienie może być zagrożone.

\section{BIBLIOGRAFIA}

Bórawski P. 2008. Ocena składników bilansu majątkowego przedsiębiorstw na przykładzie województwa warmińsko-mazurskiego. Zesz. Nauk. SGGW, Ekonomika i Organizacja Gospodarki Żywnościowej 64, 215-225.

Czarnecki M. 2011. Wzrost a rozwój przedsiębiorstwa. Zesz. Nauk. UE Pozn. 187, 43-52.

Czekaj J., Dresler Z. 2011. Zarządzanie finansami przedsiębiorstw. Podstawy teorii, Warszawa, Wydaw. PWN, 216-218.

Gabrusewicz W. 2014. Analiza finansowa przedsiębiorstwa. Teoria i zastosowanie. Warszawa, Wydaw. PWE, 243. 
Kożuch B. 2008. Nauka o organizacji, Warszawa, Wydaw. Fachowe CeDeWu, 106.

Mechanizmy i obszary przeobrażeń w organizacjach. 2007. Red. A. Potocki Warszawa, Wydaw. Difin.

Micuła I. 2013. Globalne uwarunkowania funkcjonowania i rozwoju przedsiębiorstw. Zarządz. Finanse 1, 174.

Mitek A. 2012. Współczesne determinanty rozwoju przedsiębiorstw prywatnych. Stud. Pr. WNEiZ, 28, 53-66.

Nowak E. 2017. Analiza sprawozdań finansowych. Warszawa, Wydaw. PWE, 176-178.

Penc J. 1997. Leksykon biznesu. Warszawa, Agencja Wydaw. Placet, 381.

Pierścionek Z. 1998. Strategie rozwoju firmy. Warszawa, Wydaw. PWN, 45.

Rozwój przedsiębiorstw. Modele, czynniki, strategie. 2002. Red. M. Białasiewicz. Szczecin, Wydaw. Nauk. USzczec.

Rybicki P. 2004. Sprawozdanie finansowe źródłem informacji o firmie. Warszawa, Wydaw. Poltex, 108-110.

Sierpińska M., Jachna, T. 2006. Ocena przedsiębiorstwa według standardów światowych. Warszawa, Wydaw. PWN, 144.

Siudek T. 2004. Analiza finansowa podmiotów gospodarczych. Warszawa, Wydaw. SGGW, 192.

Stefko O., Łącka I. 2017. Analiza Ekonomiczna przedsiębiorstw agrobiznesu. Poznań, Wydaw. UPrzyrod.

Szymańska E. 2010. Efektywność przedsiębiorstw-definiowanie i pomiar. Rocz. Nauk Roln. 97, 152-164.

Streszczenie. Badaniem objęto grupę 103 przedsiębiorstw w przypadku, których możliwe było uzyskanie pełnych danych finansowych z lata 2008-2014. W grupie tej znalazło się 28 przedsiębiorstw mikro, 63 małych i 12 średnich. W badanym okresie notowano wzrost ogólnego poziomu zadłużenia badanych przedsiębiorstw oraz wysoki udział obcych źródeł finansowania. Ogólna zyskowność sprzedaży usług transportowych badanych przedsiębiorstw była na stosunkowo niskim poziomie. Wzrost przedsiębiorstw w badanym okresie był finansowany głównie poprzez zaciąganie zobowiązań finansowych, co skutkowało wzrostem ogólnego zadłużenia w 2014 r. o 32,9\%, w stosunku do 2008 r. 
